\title{
Toxic epidermal necrolysis
}

INSERM

\section{Source}

INSERM. (1999). Orphanet: an online rare disease and orphan drug data base. Toxic epidermal necrolysis. ORPHA:537

Lyell syndrome is an extended form of toxic epidermal necrolysis (see this term) characterized by destruction and detachment of the skin epithelium and mucous membranes involving more than $30 \%$ of the body surface area. 